\title{
Damage control surgery: are we losing control over indications?
}

\section{Cirurgia de controle de danos: estamos perdendo controle das indicações?}

Silvânia Klug Pimentel, tCBC-PR'; Tulio Rucinski'; Melina Paula de Araújo Meskau'; Guilherme Pasquini Cavassin, AcCBC-PR; Nathan Harmuch Kohl ${ }^{1}$

\section{A B S T R A C T}

\begin{abstract}
Objective: to analyze the surgeons' subjective indications for damage control surgery, correlating with objective data about the patients' physiological state at the time the surgery was chosen. Methods: we carried out a prospective study between January 2016 and February 2017, with 46 trauma victims who were submitted to damage control surgery. After each surgery, we applied a questionnaire to the attending surgeon, addressing the motivations for choosing the procedure. We collected data in the medical records to assess hemodynamic conditions, systolic blood pressure and heart rate on arrival at the emergency room (grade III or IV shock on arrival at the emergency room would partially justify the choice). We considered elevation of serum lactate level, prolonged prothrombin time and blood pH below 7.2 as laboratory indicators of worse prognosis, objectively corroborating the subjective choice of the procedure. Results: the main indications for damage control surgery were hemodynamic instability (47.8\%) and high complexity lesions (30.4\%). Hemodynamic and laboratory changes corroborated the choice in $65.2 \%$ of patients, regardless of the time; $23.9 \%$ presented hemodynamic changes compatible with degree III and IV shock, but without laboratory alterations; $4.3 \%$ had only laboratory abnormalities and $6.5 \%$ had no alterations at all. Conclusion: in the majority of cases, there was early indication for damage control surgery, based mainly on hemodynamic status and severity of lesions, and in $65.2 \%$, the decision was compatible with alterations in objective hemodynamic and laboratory data.
\end{abstract}

Keywords: Trauma centers. General surgery. Advanced Trauma Life Support Care. Wounds and Injuries. Laparotomy.

\section{INTRODUCTION}

Patie atients sustaining severe trauma suffer from physiological and metabolic changes that often culminate in the dreaded "lethal triad" (metabolic acidosis, hypothermia and coagulopathy) ${ }^{1}$. Attempts to treat all lesions in the same procedure were already ineffective and became prohibitive due to high perioperative mortality rates. In the mid-1980s, a three-step approach aimed at controlling fatal injuries: control of bleeding and contamination of the abdominal cavity, stabilization of the patient and return to the operating room for definitive repair of all lesions. The improvement in survival in this group of patients established the concept of damage control surgery (DCS) as the procedure of choice in patients with multiple lesions of high complexity².

Despite being the procedure of choice for severely injured patients, DCS is associated with serious complications, such as enteric fistulas, readmissions, multiple surgical interventions and reduction of quality of life ${ }^{3-6}$. To date, there is no defined standard for its indication, and it is necessary to weigh risk and benefit in emergency situations ${ }^{7}$. In 2012, it was shown that the use of temporary abdominal closure in patients with less severe lesions led to an increase in morbidity ${ }^{8}$. Thus, there are variations in the indications of a procedure that is not free from complications and raises the concern about possible unnecessary indications ${ }^{9}$.

DCS is associated with a high mortality rate of $35 \%$, possibly related to the severity of the patients state who undergo the procedure ${ }^{10}$. Patients with severe metabolic acidosis - blood $\mathrm{pH}$ lower than 7.2 - have $60 \%$ higher rates of hemorrhage secondary to coagulopathy ${ }^{11}$. Increasing serum lactate levels associated

1 - Hospital do Trabalhador, Federal University of Paraná, Curitiba, PR, Brazil. 
with decreases in systolic blood pressure (SBP) also significantly aggravate the mortality rate - levels above $4,0 \mathrm{mg} / \mathrm{dL}$ associated with SBP between 70 and $90 \mathrm{mmHg}$ present a mortality rate of approximately $30 \%{ }^{12}$. Initial prothrombin (PT) activity time (longer than 14 seconds) in polytrauma patients is considered an isolated predictor of mortality, with a $35 \%$ higher risk of death ${ }^{13}$.

Our Service is a reference in trauma care in a capital city with high crime and automobile accidents rates, with frequent indication of DCS. The objective of this study was to evaluate whether the indications of this technique were consistent with the severity of the patients selected and to analyze whether or not there was over-reporting indication.

\section{METHODS}

We conducted a prospective study at the Hospital do Trabalhador, a reference center for trauma care in Curitiba, State of Paraná (PR), and metropolitan region. The study included 46 patients admitted between January 2016 and February 2017, victims of penetrating or closed trauma, who underwent DCS. There was no intervention in the management of these patients. The study was approved by the Ethics Committee of the Hospital do Trabalhador under the number 50805415.0.0000.5225.

After each surgery, we applied a questionnaire of three simple questions to the surgeon in charge. We conducted the interviews via cell phone text messages or in person. The first question was about the time when the surgeon opted for DCS, the options being before the patient's arrival at the emergency room (ER), as soon as the patient arrived at the ER, at the beginning of the procedure, after worsening of the condition during surgery, or at another time (in this case, the surgeon would specify the moment of choice). The second question addressed the reason for the DCS indication, and the options were hemodynamic state of difficult control, lesions of high complexity, lesions of multiple intestinal loops, cardiorespiratory arrest, cardiac or large vessel lesions, or another reason (in this case, the surgeon would specify the reason). The third question asked how long thereafter the surgeon would indicate reoperation, regardless of whether it actually happened or not.

We also collected objective data in the charts to assess patients' general physiological status. We selected systolic blood pressure (SBP) and heart rate (HR) to evaluate the hemodynamic condition. For assessment of the metabolic state, we chose blood pH, lactate and PT (all correlated with worse prognosis). We obtained the data upon arrival of the patient to the ER, and they reflected the possible development of the triad of death. Arterial blood gas sampling is routinely performed in severe patients upon arrival at our institution.

The choice for DCS is often subjective. We considered changes in HR and SBP compatible with grade III or IV hypovolemic shock as partial criteria for DCS choice. The procedure indication was justified if the patient also had at least one of the following laboratory criteria: serum lactate level above 4,0 mmol/L (reference value $0.5-2.2$ ) when SBP was above $90 \mathrm{mmHg}$ or $2.5 \mathrm{mg} / \mathrm{dL}$ if associated with SBP lower than $90 \mathrm{mmHg}$; presence of severe metabolic acidosis, with blood pH below 7.2; or PT over 14 seconds. The hemodynamic instability associated with alterations in laboratory tests would justify the choice, since hemorrhage is the cause of the lethal triad, and when associated with the laboratory abnormalities described above, the prognosis worsens.

There was no analysis of comorbidities associated with the procedure or late mortality.

We made the descriptive statistical analysis of the data collected in this study by means of relative frequency, absolute frequency, mean and median. For inferential statistical analysis, we used the Kuskall-Wallis test: we grouped patients according to the moment of DCS choice, and evaluated if the groups were composed of different populations based on the laboratory and hemodynamic variables of each patient - pH, lactate, systolic blood pressure, HR and PT.

\section{RESULTS}

The mean age was 34.2 years \pm 17.4 , and $97.8 \%(n=45)$ were males. The mechanisms of trauma were gunshot wound in $60.9 \%(n=28)$, stabbing wound in $10.9 \%(n=5)$, trampling in $8.7 \%(n=3)$, auto-auto 
collision in $6.5 \%(n=3)$, fall from height in $4.3 \%(n=2)$ and motorcycle accident in $2.2 \%(n=1)$. The survival rate was $80.4 \%(n=37)$, with nine deaths. The majority of the cases, $65 \%(n=30)$, were attended between Friday and Sunday, and the most prevalent time range between $18 \mathrm{~h}$ and $23: 59 h$, with $43.4 \%(n=20)$ of cases.

We applied most of the questionnaires, 95.6\%, via cell phone text messages $(n=44)$. Regarding the answers to the first question, $4.3 \%$ of the surgeons ( $n=2)$ took the decision to control the damage before the patient arrived at the $E R, 26.1 \%(n=12)$ opted for it as soon as the patient reached the $E R, 56.5 \%(n=26)$ decided early in the surgery, and $10.8 \%(n=5)$ decided upon worsening of the condition during surgery (Table 1).

Table 1. Average results of laboratory tests according to the time of DCS choice.

\begin{tabular}{lcccccc}
\hline \multicolumn{1}{c}{ Moment of choice } & N & SBP & HR & Ph & Lactate & PT \\
\hline Before reaching the ER & 2 & 90 & 129 & 7.02 & 7.985 & 21.95 \\
Upon arrival at the ER & 12 & 89.6 & 116 & 7.19 & 4.66 & 11.2 \\
At the beginning of surgery & 26 & 87.65 & 103 & 7.21 & 4.34 & 12.92 \\
After worsening during surgery & 5 & 92.8 & 105 & 7.27 & 4.868 & 18.84 \\
In another moment & 1 & PAM 40 & 129 & 6.71 & 18.85 & 13.5 \\
General & 46 & 80.3 & 108 & 7.19 & 4.7 & 13.5 \\
p-value & - & 0.5067 & 0.09 & 0.289 & 0.1506 & 0.1307 \\
\hline
\end{tabular}

ER: Emergency Room; SBP: systolic blood pressure, in $\mathrm{mmHg}$; HR: heart rate, in beats per minute; Lactate level, in serum $\mathrm{mmol} / \mathrm{L}$; PT: prothrombin time activity, in seconds.

Regarding the reason that led to DCS: in loops; $2.2 \%(n=1)$, cardiorespiratory arrest; in $2.2 \%$ $47.8 \%(n=22)$ of the cases it was the hemodynamic $(n=1)$, cardiac or large vessel lesions; and in $8.7 \%(n=4)$, state of difficult control; in 30.4\% ( $n=14)$, lesions of high other reasons (Table 2$)$.

complexity; in $8.7 \%(n=4)$, multiple lesions of intestinal

Table 2. Average results of laboratory tests according to the reason for DCS.

\begin{tabular}{lcccccc}
\hline \multicolumn{1}{c}{ Reason } & N & SBP & HR & Ph & Lactate & PT \\
\hline Hemodynamic state of difficult control & 22 & 85.56 & 104 & 7.17 & 5.96 & 13.39 \\
Highly complex lesions & 14 & 88.92 & 110 & 7.25 & 3.27 & 11.82 \\
Multiple lesions in the intestinal loops & 4 & 95 & 102 & 7.21 & 2.48 & 12.8 \\
Cardiopulmonary arrest & 1 & 80 & 120 & 7.36 & 4.01 & 12.2 \\
Heart or great vessels injuries & 1 & 120 & 110 & 7.28 & 2.81 & 14.5 \\
Other & 4 & 102.5 & 126 & 7.14 & 4.43 & 18.9 \\
General & 46 & 89 & 108 & 7.19 & 4.7 & 13.5 \\
p-value & - & 0.298 & 0.53 & 0.467 & 0.007 & 0.05 \\
\hline
\end{tabular}

SBP: systolic blood pressure, in $\mathrm{mmHg}$; HR: heart rate, in beats per minute; Lactate level, in serum mmol/L; PT: prothrombin time activity, in seconds.

In the third question, $78.3 \%(n=36)$ of the surgeons answered that they would indicate reoperation between 24 and 48 hours, 17.4\% (n=8) after 48 hours and $4.3 \%(n=2)$ between 12 and 24 hours, and none would indicate before 12 hours. The Kuskall-Wallis test showed no differences between the groups of patients divided by the time of DCS choice, although the results displayed different medians. The sample was, therefore, homogeneous ( $p>0.05$ ). The same occurred by grouping the patients according to question 2 (reason for the 
choice), except in the patient whose indication was cardiorespiratory arrest.

Since the patients constituted a homogeneous sample according to the moment of choice and preestablished criteria, we considered that hemodynamic and laboratory changes that corroborated the choice for DCS were present in $65.2 \%(n=30)$ of patients, regardless of the moment of choice. Eleven (23.9\%) presented hemodynamic changes compatible with grade III and IV shock, but without laboratory abnormalities, $4.3 \%(n=2)$ presented only laboratory abnormalities, and $6.5 \%(n=3)$, none.

Eighteen (39.1\%) reoperations occurred at the time indicated by the surgeon in the third question. In $10.8 \%(n=5)$, reoperation occurred before the expected time, in $30.4 \%(n=14)$, after, and the remaining 19.5\% $(n=9)$ patients died before reoperation.

\section{DISCUSSION}

The epidemiological profile of the cases reinforces what we already know: the greatest cause of death in young men is trauma, which is illustrated by the fact that practically all victims are male and most are of working age and at increased exposure to alcohol, illicit drugs and violent behavior. Another fact, also known and proven by our work, is represented by the majority of visits occurring on weekends and at night or dawn, when exposure to risk situations is also more prevalent ${ }^{14}$.

Most of the traumas were penetrating injuries, predominantly by gunshots. Curitiba is in fact a metropolis with high homicide rates due to this mechanism of trauma and within the national average ${ }^{15}$. We did not analyze whether the morbimortality of the victims of penetrating trauma was different from that of blunt trauma.

The use of text messages facilitated the application of questionnaires and the recording of responses. Regarding responses, we noticed that most decisions for damage control were early, based mainly on the hemodynamic instability and the severity of the lesions. In the general average, the victims had signs of hypovolemic shock, since they were hypotensive and tachycardic. The mean serum lactate level was $4.94 \mathrm{mmol} / \mathrm{L}$ and the mean $\mathrm{pH}$ was 7.04. These changes combined are associated with worse prognosis and higher mortality rates $^{12}$

The less altered laboratory test was PT, with abnormality in only $26 \%$ of the patients. The main hypothesis for the late widening of PT is the fact that the coagulation factors are altered only after the installation of metabolic acidosis and hypothermia. Another possible explanation might be the influence of early volume replacement, with plasma infusion and coagulation factors. Perhaps the use of thromboelastography (TEG) would better evaluate coagulopathy, since it can assess all phases of coagulation ${ }^{16}$. However, this test is not available at the hospital where the study was performed.

Hemodynamic and laboratory changes that justified DCS occurred in $65.2 \%$ of all patients, a result that answers our first question: "did this group really need damage control or could it have undergone only repair surgery?" The second question was whether the remaining $34.8 \%$ of the patients needed DCS, since $23.9 \%$ presented only hemodynamic changes, $4.3 \%$ had only laboratory abnormalities, and $6.5 \%$ had no alterations. An important point that could justify the choice for damage control in these cases is that our study was cross-sectional and we collected the data from the examinations made on arrival at the emergency room. This group of patients could therefore be starting to develop the lethal triad.

Another justification in favor of DCS is that the choice relies not only on laboratory data, but also on the severity of the lesions or the mechanism of the trauma. The overall mortality of our patients was $19.6 \%$, lower than the $28-35 \%$ reported in the literature. This is another corroboration of the choice for DCS. The literature also cites that the lower the physiological changes, the better the DCS prognosis, which could justify the choice in patients with only hypovolemic shock. However, doubt remains whether they could have undergone repair in a single procedure. We should not rule out the possibility of over-reporting in the $6.5 \%$ without any alterations.

The DCS should be used to reduce the chances of death by the lethal triad. The general profile of the cases studied were very serious patients, with signs of hypovolemic shock, a significant increase in serum lactate levels, and a decrease in $\mathrm{pH}$. This set of data pointed to a higher risk of death. 
Based on the previously mentioned criteria used to assess hemodynamic and metabolic status, we observed that among the patients studied, $65.21 \%$ presented changes correlated with worse prognosis. This means that in most cases the damage control surgery was properly indicated. The low mortality rate also ratifies the choice for this strategy.

\title{
R E S U M O
}

\begin{abstract}
Objetivo: analisar as indicações subjetivas, por parte do cirurgião, para cirurgia de controle de danos, correlacionando com dados objetivos sobre o estado fisiológico do paciente, no momento em que a cirurgia foi escolhida. Métodos: estudo prospectivo realizado entre janeiro de 2016 e fevereiro de 2017, de 46 pacientes vítimas de traumas e submetidos à cirurgia de controle de danos. Após cada cirurgia era aplicado um questionário ao cirurgião responsável, abordando as motivações para a escolha do procedimento. Foram coletados dados nos prontuários para avaliar as condições hemodinâmicas, pressão arterial sistólica e frequência cardíaca na chegada ao pronto socorro (choque grau III ou IV na chegada ao pronto socorro justificaria parcialmente a escolha). Elevação do nível sérico de lactato, tempo de protrombina alargado e pH abaixo de 7,2 foram usados como indicadores laboratoriais de pior prognóstico, corroborando objetivamente com a escolha subjetiva pela cirurgia de controle de danos. Resultados: as principais indicações para cirurgia de controle de danos foram instabilidade hemodinâmica $(47,8 \%)$ e lesões de alta complexidade (30,4\%). Alterações hemodinâmicas e laboratoriais corroboraram a escolha em 65,2\% dos pacientes, independente do momento; $23,9 \%$ apresentaram alterações hemodinâmicas compatíveis com choque grau III e IV, porém sem alterações laboratoriais; 4,3\% apresentavam somente as alterações laboratoriais e 6,5\% estavam sem alteração alguma. Conclusão: na maioria dos casos optou-se precocemente pela cirurgia de controle de danos, baseando-se principalmente no estado hemodinâmico e gravidade das lesões, sendo que em 65,2\% a decisão foi compatível com alterações de dados objetivos do estado hemodinâmico e laboratoriais.
\end{abstract}

Descritores: Centros de Traumatologia. Cirurgia Geral. Cuidados de Suporte Avançado de Vida no Trauma. Ferimentos e Lesões. Laparotomia.

\section{REFERENCES}

1. Burch JM, Ortiz VB, Richardson RJ, Martin RR, Mattox $\mathrm{KL}$, Jordan GL Jr. Abbreviated laparotomy and planned reoperation for critically injured patients. Ann Surg. 1992;215(5):476-84.

2. Rotondo MF, Schwab CW, McGonigal MD, Phillips GR 3rd, Fruchterman TM, Kauder DR, et al. "Damage control": an approach for improved survival in exsanguinating penetrating abdominal injury. J Trauma. 1993;35(3):375-82; discussion 382-3.

3. Cheatham ML, Safcsak K, Llerena LE, Morrow CE Jr, Block EF. Long-term physical, mental, and functional consequences of abdominal decompression. J Trauma. 2004;56(2):237-41; discussion 241-2.

4. Dubose JJ, Scalea TM, Holcomb JB, Shrestha B, Okoye O, Inaba K, Bee TK, Fabian TC, Whelan J, Ivatury RR; AAST Open Abdomen Study Group. Open abdominal management after damage-control laparotomy for trauma: a prospective observational American Association for the Surgery of Trauma multicenter study. J Trauma Acute Care Surg. 2013;74(1):11320; discussion 1120-2.

5. Cheatham ML, Safcsak K. Longterm impact of abdominal decompression: a prospective comparative analysis. J Am Coll Surg. 2008;207(4):573-9.

6. Sutton E, Bochicchio GV, Bochicchio K, Rodriguez ED, Henry S, Joshi M, et al. Long term impact of damage control surgery: a preliminary prospective study. J Trauma. 2006;61(4):831-4; discussion 835-6.

7. Flin R, Youngson $G$, Yule $S$. How do surgeons make intraoperative decisions? Qual Saf Health Care. 2007; 16(3):235-9.

8. Schreiber MA. The beginning of the end for damage control surgery. Br J Surg. 2012;99 Suppl 1:10-1.

9. Martin MJ, Hatch Q, Cotton B, Holcomb J. The use of temporary abdominal closure in low-risk trauma patients: helpful or harmful? J Trauma Acute Care Surg. 2012;72(3):601-6; discussion 606-8.

10. Stone HH, Strom PR, Mullins RJ. Management of the major coagulopathy with on set during laparotomy. Ann Surg. 1983;197(5):532-5. 
11. Aoki N, Wall MJ, Demsar J, Zupan B, Granchi T, Schreiber MA, et al. Predictive model for survival at the conclusion of a damage control laparotomy. Am J Surg. 2000;180(6):540- 4; discussion 544-5.

12. Odom SR, Howell MD, Silva GS, Nielsen VM, Gupta A, Shapiro NI, et al. Lactate clearance as a predictor of mortality in trauma patients. J Trauma Acute Care Surg. 2013;74(4):999-1004.

13. MacLeod JB, Lynn M, McKenney MG, Cohn SM, Murtha M. Early coagulopathy predicts mortality in trauma. J Trauma. 2003;55(1):39-44.

14. Lima SO, Cabral FLD, Pinto Neto AF, Mesquita FNB, Feitosa MFG, Santana VR de. Avaliação epidemiológica das vítimas de trauma abdominal submetidas ao tratamento cirúrgico. Rev Col Bras Cir. 2012;39(4):302-6.

15. Waiselfsz JJ. Mapa da violência 2016. Homicídios por armas de fogo no Brasil. PDF file. Rio de Janeiro:
FLACSO/CEBELA; 2016. Available from: http:// www.mapadaviolencia.org.br/pdf2016/Mapa2016_ armas_web.pdf

16. Nascimento Jr B, Scarpelini S, Rizoli S. Coagulopatia no trauma. Medicina, Ribeirão Preto. 2007;40(4):509-17.

Received in: 03/09/2017

Accepted for publication: 26/10/2017

Conflict of interest: none.

Source of funding: none.

\section{Mailing address:}

Tulio Rucinski

E-mail: rucinskitulio@gmail.com /

tulio.rucinski@hotmail.com

(cc) BY 